\title{
ZAPOMNIANA SZTUKA LECZENIA. HANS-GEORG GADAMER O HUMANISTYCZNYM WYMIARZE ZDROWIA I CHOROBY
}

Hans-Georg Gadamer, O skrytości zdrowia, przeł. A. Przyłębski. Wydawnictwo Media Rodzina, Poznań 2011.

Nieczęsto ma się okazję czytać rzecz tak niezwyczajną, jak O skrytości zdrowia Hansa-Georga Gadamera. Książka ta, będąca zbiorem trzynastu esejów - z których część to spisane, a wcześniej przez autora wygłoszone wykłady - jest bowiem prezentacją głęboko humanistycznego spojrzenia na problem zdrowia, choroby i sztuki leczenia. Przyznać trzeba, że wymienione zagadnienia rzadko stają się przedmiotem współczesnych rozpraw filozoficznych, a jeśli już tak się dzieje, to są omawiane z punktu widzenia krytyki systemu i mniej lub bardziej naznaczone ideologicznym podejściem. W przypadku O skrytości zdrowia mamy do czynienia z czymś zgoła odmiennym, oto jeden z najwybitniejszych filozofów XX wieku, hermeneuta, autor kluczowych dla rozwoju humanistyki prac, pochyla się nad problemami medycyny i czyni to, można by rzec, w duchu starożytnych wzorców.

Przedmiotem wszystkich zebranych w tomie esejów są pojęcia zdrowia i choroby, w tym również choroby psychicznej, której Gadamer poświęca osobny szkic, a także problemy służby zdrowia, relacji pacjent-lekarz, terapii i autoterapii czy wreszcie śmierci. Uprawnionym byłby z pewnością zarzut braku profesjonalizmu autora, bo wszak powyższe tematy nie są typowo filozoficznymi. Gadamer jednak nie próbuje temu zaprzeczyć, kilkakrotnie przyznaje, że jest w tych kwestiach laikiem, lekarzem nigdy nie był, a pacjentem 
wciąż nie bardzo się poczuwa. Jednak mimo to, a może właśnie dzięki temu, podejmuje się zmierzenia $\mathrm{z}$ tematami jakby nie patrzeć przyrodoznawczymi, z pozycji humanisty, i właśnie to przesądza o sukcesie O skrytości zdrowia. Autor nie sili się na włączenie swych rozważań w czysto medyczny dyskurs, wie bowiem doskonale, że wówczas skazany byłby na niepowodzenie; przeciwnie, osadza je w kontekście polityczno-społecznym i filozoficznym, nie unikając także refleksji językoznawczych.

Zauważyć koniecznie należy, że książka ta nie jest pracą stricte naukową, jej charakter jest raczej popularnonaukowy czy publicystyczny, o czym świadczy choćby sama forma zebranych esejów. Nie jest to jednak wyłącznie zbiór luźnych refleksji, Gadamer, zachowując naukową formę (przypisy, cytowanie etc.), pozwala sobie na prowadzenie wywodu w sposób swobodny, dygresyjny, eseistyczny właśnie, co czyni lekturę atrakcyjną i zajmującą. Miast referować stanowiska kolejnych myślicieli i naukowców, prezentuje raczej własne spostrzeżenia i uwagi oraz komentuje popularne sądy. Niezwykle często stawia pytania, zdaje się głośno myśleć, podaje czytelnikowi pod rozwagę niektóre problemy, stara się sam nie przesądzać. Unikając skomplikowanych filozoficznych wywodów, hermetycznej aparatury pojęciowej i niejasnych konstrukcji wypowiedzi, Gadamer czyni swoją pracę dostępną szerszym kręgom czytelników, co zresztą zapewne było od początku założeniem, zważywszy na pierwotny wykładowy charakter niektórych esejów (Gadamer wygłaszał je w środowiskach lekarskich). W miejsce zawiłych, stricte filozoficznych rozmyślań, autor przytacza anegdoty, historyjki i - jak sam pisze - żarty, co sprawia, że eseje stają się przystępnymi i atrakcyjnymi. Nierzadko także przywołuje wątki autobiograficzne, głównie związane ze swoją naukowo-instytucjonalną aktywnością. Co istotne, O skrytości zdrowia trudno zaliczyć do prac z dziedziny socjologii zdrowia, jak można by sądzić po nakreślonym tu dotychczas charakterze pracy, nie spełnia bowiem wymogów tej dyscypliny. Nie jest to jednak zarzut - prac z tej dziedziny jest bowiem całkiem sporo, natomiast takich, jak ta Gadamerowska, praktycznie brak.

Co zatem przesądza o niezwykłości tej lektury? Przede wszystkim, implicytnie (z wyjątkiem ostatniego rozdziału, Hermeneutyka i psychiatria, gdzie pisze o tym wprost) przyjęte przez autora hermeneutyczne podejście. Gadamer apologetyzuje mianowicie kwestie interpretacji, języka i rozmowy, za każdym razem stawiając człowieka i jego doświadczenie w centrum zainteresowań. Z takiego punktu widzenia przygląda się relacjom pacjent-lekarz, problemom samego pacjenta, przebiegowi leczenia i terapii, a także samopoczucia i autoterapii jako wewnętrznego dialogu pacjenta z samym sobą. Szczególne skupienie na języku przejawia się także w filologicznym zamiłowaniu Gadamera do odwoływania się do etymologii omawianych pojęć, tutaj także ujawnia się w pełni fascynacja autora staroży tną myślą grecką oraz 
znakomita jej znajomość. Omawianie niemalże każdego kolejnego podejmowanego na kartach książki problemu autor rozpoczyna od sięgnięcia do źródłosłowu określającego go pojęcia i przytoczenia adekwatnego stanowiska antycznego filozofa - cytuje głównie Sokratesa i Platona, ale także odwołuje się do starożytnej sztuki, wspominając choćby o Ajschylosie. Gwoli ścisłości dodać należy, że autor Prawdy i metody nie ogranicza się wyłącznie do powoływania się na antyczne korzenie myśli humanistycznej, wspomina bowiem także o spostrzeżeniach Kartezjusza, Kanta, Hegla czy Nietzschego, jednak znacznie rzadziej niż wspomnianych starożytnych Greków.

Starając się uniknąć streszczania O skrytości zdrowia, chciałabym poświęcić kilka słów treści tej książki. Tytułowe zjawisko polega, mówiąc krótko, na swoistej niezauważalności zdrowia w momencie jego trwania, lecz dopiero gdy pojawia się choroba. Jak zauważa sam autor, powrót do zdrowia polega na „zapomnieniu, że jest się chorym" ${ }^{1}$, a fakt troski o zdrowie stanowi „pierwotny fenomen bycia człowiekiem" ${ }^{2}$. Ale, dodajmy, choć tytuł na to nie wskazuje, że Gadamer pisze też o skrytości śmierci: nikt nie jest w stanie przeżyć swojej śmierci, nigdy więc nie dowie się, jaka jest jej istota. To kolejna tajemnica wpisana w ludzki byt, o której nie umiemy i nie chcemy pamiętać. Autor już w przedmowie nakreśla prawdziwie humanistyczną perspektywę, jaką obrał dla całości swojej pracy. Doświadczanie bycia zdrowym, chorowania, powrotu do zdrowia, kontaktu z lekarzem, służbą zdrowia czy kwestii ekonomicznych związanych z leczeniem, przemysłem farmaceutycznym i wielu innych, są doświadczeniami wspólnymi dla wszystkich ludzi, nie tylko lekarzy czy pacjentów. Przenikliwe spojrzenie Gadamera ukazuje wyżej wymienione problemy w całkiem innej perspektywie. Wychodząc od rozróżnienia teorii, praktyki i techniki oraz przedstawienia przemian $\mathrm{w}$ ich wzajemnych relacjach na przestrzeni czasu i historii nauk, zarówno humanistycznych jak i przyrodoznawczych, autor szkicuje współczesny stan nauki i sztuki (rozumianej jako zbiór umiejętności), związków natury i kultury, cybernetyki czy postępującej specjalizacji wiedzy. Wszystko to, jego zdaniem, powoduje odchodzenie od holistycznych ujęć, a co za tym idzie, "gubi" bezpowrotnie człowieka, jako swój podmiot i przedmiot. Nie chcąc rekonstruować tu całości wywodu, wspomnę tylko o jednym $\mathrm{z}$ ustalen, które $\mathrm{z}$ jednej strony sam autor uczynił kluczowym dla omawianego zbioru esejów, z drugiej mnie samej wydaje się najbardziej istotnym i poruszającym. Mam na myśli pojęcie „sztuki leczenia" jako specyficznej umiejętności lekarskiej, której produktem nie jest, jak w przypadku tradycyjnie rozumianej sztuki, żadne dzieło, a więc żaden sztuczny, artefaktyczny wytwór, lecz przywrócenie pacjenta do stanu natury,

\footnotetext{
${ }^{1}$ Hans-Georg Gadamer, O skrytości zdrowia, tłum. A. Przyłębski, Wyd. Media Rodzina, Poznań 2011, s. 8.

2 Tamże, s. 9.
} 
do równowagi. To także niejako wyłącza sztukę leczenia, medycynę, z obszaru nauk przyrodniczych i umieszcza w osobnej kategorii nauk o człowieku. Przyznać trzeba, że współcześnie łatwo zapomnieć o źródłach medycznej praktyki i zawodu lekarza, stąd też spostrzeżenia Gadamera znajduję jako rzeczywiście ważne i odświeżające. Podobnie, rozważania na każdy kolejny obrany temat autor sytuuje w możliwie szerokim, humanistycznym, społeczno-filozoficznym kontekście. I tak, pisząc o śmierci, obszernie przywołuje mityczne greckie przekazy, Dialogi platońskie czy teologiczne teorie, odnosząc je przy tym do współczesnego świata. Porusza tak aktualne obecnie problemy jak autorytet lekarza, kwestie godności pacjenta czy dehumanizacji procesu leczenia. Co warte zauważenia, Gadamer nie ogranicza się do stwierdzenia faktów i przypomnienia starożytnych ustaleń, uruchamia także kolejny wymiar, przechodzi mianowicie od pytania: „jak jest?" do: „jak powinno być?" i daje jasne, konkretne wskazówki, chociażby pisząc wprost o powinnościach lekarza. Wskazówki te są wprawdzie nieco idealistyczne, rzec nawet można, utopijne, a przez to współcześnie trudne do realizacji, nie ujmuje to im jednak słuszności i trafności.

Na podstawie nakreślonych tu uwag stwierdzić można, że zbiór esejów O skrytości zdrowia nie jest pracą odkrywczą, nie wnosi bowiem nic nowego do nauk medycznych czy społecznych mających za swój przedmiot zagadnienia zdrowia i medycyny. Rozczaruje też z pewnością miłośników Gadamera - filozofa, fundatora hermeneutyki filozoficznej, znanego z Prawdy $i$ metody czy Aktualności piękna. Jednakże, jeśli czytać ją wyzbywszy się takich oczekiwań, książka ta potrafi prawdziwie zainteresować, zachęcić do zatrzymania się przy problemach, które od zawsze wydawały się oczywiste, a po lekturze już takimi się nie jawią. Skrytość zdrowia i śmierci, troska o własne zdrowie i samopoczucie, problem rozumienia swojego ciała i duszy jako całości oraz uwikłanie w medyczne relacje i zależności, są stałymi elementami ludzkiego życia, które, choć dziś strywializowane i pozbawione humanistycznego wymiaru, pozostaja fundamentami naszego bytowania. Hans-Georg Gadamer zaprasza do sięgnięcia do ich źródeł, ponownego zrozumienia i w efekcie odkrycia na nowo. 